\title{
Scams and spamnals
}

\section{John Launer}

My internet provider, like most, carries advertisements on its home page. A recent one for a dating agency invited me to enter my age, postcode and relationship preferences into a menu. For fun, I entered my details as a 95-year-old woman living in the Outer Hebrides, seeking love with an older woman. The site immediately informed me there were several suitable contacts obtainable-on payment of a fee. A similar ad the next day, for a genealogy agency, offered to trace all my relatives around the world. In the spirit of the previous exercise I entered the name Flora McFinkelstein into the menu and was instantly offered the contact details of 1963 people sharing the same surname, also for a fee. I wondered if the clan McFinkelstein might be holding a gay and lesbian diamond anniversary reunion on North Uist.

Scams like this are easy enough to see through unless you are terminally gullible, but there is a similar form of internet deception that is being targeted at doctors and academics and is harder to recognise. 'Spamnals' are online journals that approach professionals via mass email, inviting them to submit papers for publication on what seem like very favourable terms. This includes rapid processing, swift acceptance of papers and immediate publication with open access. Many spamnals have highly plausible titles, similar to existing and highly reputable ones: for example, 'International Archives of X-ology', when the leading journal in the field has a title like 'American Annals of X-ology.'

In a helpful guide in $B M J$ last year, Mary E Black warned readers how to spot a 'spamnal'. 'For example, if you go online to research the publishers of such spamnals, you will generally find they own scores or even hundreds of similar titles, covering medicine and every other imaginable field from literary studies to the disposal of toxic waste. If you click on one of these and try to read the contents, you are likely to find an indiscrimate hotchpotch of poor quality papers, many of which barely fit the topic the journal is meant to cover.

Correspondence to Dr John Launer, London Deanery, Stewart House, London WC1B 5DN, UK; jlauner@londondeanery.ac.uk

\section{SMALL PRINT}

Almost certainly, the authors of such articles will be young researchers who are desperate to get their research and names into print to boost their CVs and career chances. The editor will have accepted their articles with no request for any revision, while offering lavish praise from 'our distinguished editorial board', and a price list in small print for the 'processing costs' that must be met before or after publication. It will, of course, have cost the publishers absolutely nothing to put shoddy academic papers on their website, probably without even reading them.

In spite of the deception, it isn't hard to see why lots of people in the medical world are falling for these invitations. If your professor says that you must publish or perish, and the invitation from 'Recent Advances in Brachial Plexus Studies' looks plausible, it is hard for novices to believe that the 'distinguished editorial board' actually consists of a crook sitting in front of a PC on the other side of the world. Yet the fact is, there isn't a single reputable medical journal in the world that needs to solicit submissions in such a manner. (There are, of course, some decent and worthwhile online journals and platforms for research that offer open access, but they too would never trawl for authors in this way.)

\section{EXPERIMENT}

A few weeks ago I decided to find out what exactly happens when you offer something to a spamnal. I receive an average of six or seven of these invitations a week, so it wasn't hard to set up the experiment. The next invitation that arrived was from the editor of the 'Journal of Socialomics'. 'What on earth are socialomics?' you might ask. I haven't the faintest idea, but you may get the gist by looking at the first two articles in their current contents list. These are entitled 'Treatment of Urinary Incontinence in Women: A Challenge between Conservative and Surgical Therapy' and 'What Happens at Raves? Risk, Research and Harm Reduction'.

Undeterred by my ignorance of both surgical urology and raves, I wrote to the editor as follows: 'Dear Sir or Madam, I am delighted to see the first issue of this journal. Thank you for informing me. I have a considerable interest in Socialomics. I am currently working on a paper with the provisional title: "The cybernetics of drivel: a pseudo-Lacanian analysis of Boolean linguistics". Please can you let me know if this is the kind of topic you might be interested in including and, if so, how I might submit it. Best wishes.'

\section{IRRESISTIBLE PROPOSAL}

It took them nearly 2 weeks to show interest in this irresistible proposal, but sure enough they finally responded. Here was what they wrote: 'Dear Dr Launer John, Greetings from the Journal of Socialomics. We are thank ful (sic) to your reply. Your article was consider (sic) in this journal. Your article title was intereseting (sic) too. Please send me your article as soon as possible. With regards.'

I have to say I was tempted to send in a submission. I considered taking an article from one of the more incomprehensible gurus of the last century (Carl Jung or Gregory Bateson would do nicely) and copying out each third sentence, starting from the back. I even wrote to Mary E Black offering her coauthorship in the project. Sadly she declined. She told me she had written a spoof article based entirely on health policy jargon for a minor publication but it came back to haunt her when people cited it as a serious work. The last thing she needed for her reputation was an article in a spamnal as well.

In the end I decided not to take the joke any further. It would have cost me money to get the wretched thing printed, and no one would ever have read it. I also realised that no one could improve on the stunt that Alan Sokal pulled off with the famous gobbledegook paper on postmodernism that he managed to get published in a mainstream social sciences journal. ${ }^{2}$ So there the matter rests. Readers should resolutely ignore invitations from spamnals, and advise all their colleagues to do the same.

\section{Competing interests None.}

Provenance and peer review Commissioned; internally peer reviewed.

Postgrad Med J 2012;88:556

doi:10.1136/postgradmedj-2012-131317

\section{REFERENCES}

1. Black M. How to spot a "spamnal". BMJ 2011;343 d7077.

2. Sokal A. Transgressing the boundaries: towards a transformative hermeneutics of quantum gravity. Social Text 1996;46:217-52. 